\title{
Evaluation of Effects of Chemical Soil Treatments and Potato Cultivars on Spongospora subterranea Soil Inoculum and Incidence of Powdery Scab and Potato Mop-Top Virus in Potato
}

\author{
Yuan Zeng, ${ }^{1}$ Ana Cristina Fulladolsa, ${ }^{1}$ Andrew M. Cordova, ${ }^{1}$ Patrick O’Neill, ${ }^{2}$ Stewart M. Gray, ${ }^{3}$ and Amy O. Charkowski ${ }^{1, \dagger}$ \\ ${ }^{1}$ Department of Agricultural Biology, Colorado State University, 307 University Avenue, Fort Collins, CO 80523 \\ ${ }^{2}$ Soil Health Services, PBC, Alamosa, CO 81101 \\ ${ }^{3}$ United States Department of Agriculture-Agricultural Research Service and Plant Pathology and Plant-Microbe Biology Sec- \\ tion, School of Integrative Plant Science, Cornell University, Ithaca, NY 14853
}

\begin{abstract}
Spongospora subterranea is a soilborne plasmodiophorid that causes powdery scab in potato. It also transmits potato mop-top virus (PMTV), which causes necrotic arcs (spraing) in potato tubers. Three field experiments were conducted in naturally $S$. subterranea-infested soil to investigate the effects of two chemicals, Omega 500F (fluazinam) and FOLI-RPLUS RIDEZ (biological extract), on powdery scab, PMTV, and changes in $S$. subterranea inoculum with six different potato cultivars. The efficacy of soil treatment with these two chemicals on tuber lesions, root galling, and pathogen population was also assessed in greenhouse trials. The chemical treatments did not reduce powdery scab, root gall formation, or $S$. subterranea inoculum in the field or greenhouse trials.

were more tolerant to powdery scab than the yellow- or red-skinned cultivars but all were susceptible to PMTV. In the field, powdery scab indices and soil inoculum changes were positively correlated, while postharvest $S$. subterranea inoculum was positively correlated with root galling in both greenhouse trials. Powdery scab and PMTV occurred in noninoculated potting mix, indicating that peat-based potting mix is a source for both pathogens. These results demonstrate that chemical management methods currently used by farmers are ineffective, that $S$. subterranea and PMTV in potting mix can cause severe epidemics in greenhouses, and that potato cultivar choices impact inoculum increases in soil.
\end{abstract} Postharvest $S$. subterranea soil inoculum in fields varied across farms and among potato cultivars but the pathogen population consistently increased by the end of the growing season. The evaluated russet cultivars
Keywords: chemical soil treatment, potato cultivar, potato mop-top virus, powdery scab, Spongospora subterranea
The plasmodiophorid Spongospora subterranea is a soilborne protist that causes root galls of potato and powdery scab on tubers (Bittara et al. 2016; Falloon et al. 2003; Houser and Davidson 2010). The $S$. subterranea life cycle is biphasic and the pathogen can develop multiple somatic structures, including zoospores, plasmodia, zoosporangia and resting spores through its life cycle (Harrison et al. 1997; Merz 2008). The resting spores of S. subterranea can survive in the soil for over 10 years. $S$. subterranea vectors potato mop-top virus (PMTV), which causes necrotic arcs or flecks, known as spraing symptoms, in tuber flesh (Carnegie et al. 2009; Davey et al. 2014; Domfeh et al. 2015; Jones and Harrison 1969; Santala et al. 2010). In the United States, the two pathogens are growing in importance wherever potato crops are intensively grown because powdery scab and spraing symptoms limit sales and export for seed, fresh, and processing potato (Bittara et al. 2016; Davey et al. 2014; Merz 2008). The spread of these pathogens across the United States may have occurred due to the common presence of the vector in peatbased potting mixes used to grow initial seed potato stocks (Mallik

${ }^{\dagger}$ Corresponding author: A. O. Charkowski; amy.charkowski@ colostate.edu

Funding: This work was supported by the United States Department of Agriculture (USDA) National Institute of Food and Agriculture (grant SCRI 73999-10921) and the USDA Animal and Plant Health Inspection Service (award number 59-8062-001).

Any opinions, findings, conclusions, or recommendations expressed in this publication are those of the author(s) and do not necessarily reflect the view of the U.S. Department of Agriculture.

The author(s) declare no conflict of interest.

Accepted for publication 26 May 2020.

(C) 2020 The American Phytopathological Society et al. 2019). Powdery scab thrives in cool, wet, and heavy soils but the disease still occurs in environments with arid climates in the United States, South Africa, and Israel (Muzhinji and van der Waals 2019; Tsror et al. 2009). This is possibly due to irrigation, which supplies soil moisture and decreases soil temperatures to a range favorable for infection in the rhizosphere and geocaulosphere (Merz and Falloon 2009).

Limited management strategies are available for $S$. subterranea due to its biphasic life cycle and the lack of resistant potato cultivars (Merz 2008; Merz and Falloon 2009). Managing PMTV is as difficult as managing the vector because commercial potato cultivars are not resistant to this virus. Seed lots with high incidence of spraing may be stopped during shipment but there are no national certification regulations that limit the spread of soilborne diseases of potato, except for potato cyst nematode quarantines (Dandurand et al. 2019; Domfeh et al. 2015). Therefore, effectively controlling the vector on farm is required to prevent PMTV infection and spread. Over the past few decades, researchers have conducted several studies attempting to mitigate negative impacts of $S$. subterranea and PMTV. Soil organic amendments and rotation crops such as mustard, ryegrass, rapeseed, and canola may reduce powdery scab. However, the results from these methods were only promising in the fields where the disease was a serious problem (Falloon et al. 1995; Larkin and Griffin 2007; Larkin and Lynch 2018). The use of resistant potato cultivars could be an alternative strategy for powdery scab management but immunity to $S$. subterranea is not available in commercial cultivars. In field experiments conducted to assess susceptibility of commercial potato cultivars on the formation of root galls and tuber lesions, a few potato cultivars or clones were reported to have some level of resistance to the disease (Falloon et al. 2003; Houser and Davidson 2010; Merz et al. 2012; Torres et al. 1995). However, variability in field conditions can result in inconsistent disease evaluations and may provide inaccurate recommendations on cultivar selections for potato farmers (Bittara et al. 2016; Johnson and Cummings 2015; Merz and Falloon 2009; Torres et al. 1995). Other approaches such as 
the selection of planting date and the improvement of soil drainage capacity may influence powdery scab development; however, not enough studies are available to offer farmers detailed recommendations on how to use these methods to manage powdery scab (Falloon 2008).

Conventional management strategies such as chemical applications aim to reduce seed- and soilborne $S$. subterranea inoculum. Chemicals used as seed treatments such as formaldehyde, quintozene, mercury, maneb, zinc oxide, and fluazinam reduce disease incidence but some of these chemicals, including quintozene and mercury, have been banned due to their detrimental effects to the environment (Braithwaite et al. 1994; Falloon et al. 1996; Merz 2000, Nachmias and Krikun 1988; Tsror (Lahkim) et al. 2019, 2020). In recent years, more emphasis has been given to chemical reduction of soil inoculum because inoculum is widely present in potato fields and $S$. subterranea can cause severe disease even on plants grown from disease-free seed potato. However, common fungicides such as fluazinam, flusulfamide, or cymoxanil have shown inconsistent results that may be due to variations in the application method, soil inoculum level, cultivar susceptibility, or soil texture and structure (Bittara et al. 2016; Houser and Davidson 2010; Tsror et al. 2009; Wale 2000).

S. subterranea and PMTV tuber infections are becoming more common in the San Luis Valley (SLV), which is the main potato production area in Colorado, and they are among the most serious potato diseases Colorado growers face when trying to produce healthy marketable crops. Seed and fresh market potato can be downgraded or rejected by buyers due to the damage caused by either of these pathogens (Houser and Davidson 2010). Omega 500F (active ingredient fluazinam; Syngenta, Basel, Switzerland) is used by potato farmers in the United States either by application prior to bed preparation or as an in-furrow application of 3,508 $\mathrm{ml} /$ ha at planting to manage powdery scab; however, it is not used in some other potatogrowing regions such as New Zealand and Switzerland due to its phytotoxicity and lack of efficacy (Merz and Falloon 2009). Another chemical treatment, FOLI-R-PLUS RIDEZ (Future AG Products, Pasco, WA, U.S.A.; http://futureagproducts.com/biologicals), which consists of soluble phosphate, potassium, microbial metabolites, natural fermentation extracts, and organic compounds, is recommended for all soils and plants to maintain healthy roots and rhizosphere. It is currently marketed as a control for powdery scab through an infurrow application during planting and subsequent foliar sprays, even though it is labeled as a biological extract and not a pesticide.

Potato farmers currently use Omega and RIDEZ to attempt to reduce the severity and spread of S. subterranea or PMTV but no peerreviewed studies have documented the ability to control either pathogen in any major U.S. potato production area. The present study was conducted with three aims: (i) to investigate the effects of the chemical treatments on S. subterranea soil inoculum, tuber lesion incidence, or severity, and PMTV tuber necrosis incidence; (ii) to estimate cultivar responses to $S$. subterranea and PMTV; and (iii) to determine whether there is an interactive effect of chemical treatment and cultivar on both diseases and pathogens.

\section{Materials and Methods}

Field experiments. Site description and experimental design. Experiments were conducted on irrigated fields naturally infested with various levels of $S$. subterranea and with known histories of disease

Table 1. Location, soil texture, $\mathrm{pH}$, irrigation and precipitation, fertilizer application, and planting and harvest dates

\begin{tabular}{|c|c|c|c|c|c|c|c|}
\hline $\begin{array}{l}\text { Year, } \\
\text { trial }\end{array}$ & $\begin{array}{l}\text { Study } \\
\text { site }\end{array}$ & Soil texture & $\begin{array}{c}\text { Soil } \\
\text { pH }\end{array}$ & $\begin{array}{c}\text { Irrigation and } \\
\text { precipitation }(\mathbf{m m})\end{array}$ & $\begin{array}{c}\text { Nitrogen at preplanting } \\
(\mathrm{kg} / \mathrm{ha})\end{array}$ & $\begin{array}{c}\text { Phosphorus at } \\
\text { preplanting (kg/ha) }\end{array}$ & $\begin{array}{c}\text { Planting, } \\
\text { harvesting dates }\end{array}$ \\
\hline \multicolumn{8}{|l|}{2017} \\
\hline 1 & Farm A & $\begin{array}{l}\text { Graypoint gravelly } \\
\text { sandy loam }\end{array}$ & 8.0 & 356 & 79 & 92 & 17 May, October 16 \\
\hline \multicolumn{8}{|l|}{2018} \\
\hline 2 & Farm B & Sand clay loam & 7.6 & 705 & 56 & 39 & 3 May, August 31 \\
\hline 3 & Farm C & McGinty sandy loam & 8.0 & 482 & $\begin{array}{c}148 \text { with additional } 35 \text { at } \\
\text { midseason }\end{array}$ & 71 & 9 May, October 8 \\
\hline
\end{tabular}
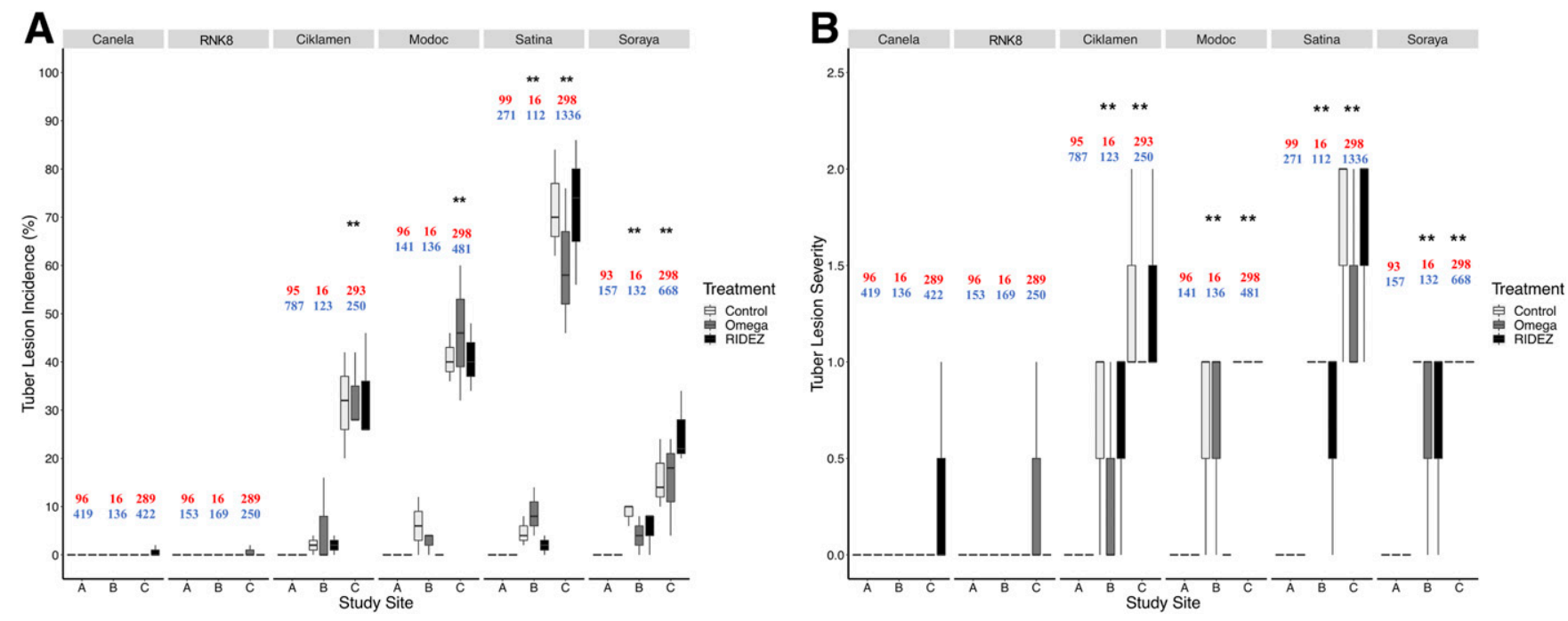

Fig. 1. Box plots of powdery scab A, incidence and B, severity between chemical treatment and control across study sites in San Luis Valley, Colorado during 2017 and 2018. Numbers in red represent means of preplanting Spongospora subterranea soil inoculum (sporosori per gram of soil) per study site, and the numbers in blue represent means of preharvesting soil inoculum. Asterisks $\left(^{\star *}\right)$ indicate a significant difference of powdery scab incidence or severity was observed in a cultivar at a specific site $(P<0.01)$. RNK8 $=$ Russet Norkotah line 8. 
in the SLV. Three trials were performed during two consecutive years at three sites (farms A, B, and C) (Table 1). Six potato cultivars which represented russet-skinned (Russet Norkotah line 8 and Canela Russet), red- skinned (Modoc and Ciklamen), and yellow-skinned (Soraya and Satina) cultivars were obtained from a certified potato grower in Colorado.

Field trials were conducted using split-plot designs, with main plots assigned to Omega, RIDEZ, or control treatment (no chemical). Subplots were assigned to cultivars, arranged in randomized complete block designs (RCBD) with three blocks. Each subplot consisted of six four-row plots, each row with 14 seed tubers planted $0.28 \mathrm{~m}$ apart. The distance between plots was $1.22 \mathrm{~m}$. Immediately prior to planting, RIDEZ at $219 \mathrm{ml} / \mathrm{ha}$ or Omega at 3,508 $\mathrm{ml} / \mathrm{ha}$ was applied in furrow. In the RIDEZ treatment, a foliar spray of $2,338 \mathrm{ml} /$ ha was applied once per month for two consecutive months after the plants emerged.

Soil sampling and determination of $\mathrm{S}$. subterranea inoculum level. In order to determine the $S$. subterranea sporosori level at planting (i.e., immediately after tubers were planted) and preharvesting, soil samples were collected in every plot using a zigzag sampling scheme with a standard 2.2-by-53-cm soil probe to a depth of approximately $20.3 \mathrm{~cm}$ (AMS, American Falls, ID, U.S.A.). Each soil sample consisted of 10 cores from a plot bulked together in a plastic bag. These were transported to the laboratory and held at room temperature until further processing. Due to plot shifting during planting, only 9 soil samples (27 total) were collected at planting per soil treatment on farms A and B. In all, 18 soil samples were collected per soil treatment on farm $\mathrm{C}$, for a total of 54 samples collected at planting. At 3 to 5 days prior to harvesting, 54 soil samples were obtained from each trial. In the laboratory, each soil sample was air dried, homogenized, and ground before DNA extraction. DNA from $0.25 \mathrm{~g}$ per soil sample was extracted using the DNeasy PowerSoil Kit (Qiagen, Hilden, Germany) and the amount of $S$. subterranea DNA was determined using a quantitative PCR (qPCR) assay by comparing to a standard curve of DNA extracted from sporosori obtained from potato tubers with powdery scab $\left(7,70,7 \times 10^{2}, 7 \times 10^{3}\right.$, and $7 \times 10^{4}$ sporosori [sp]/g of soil) (Mallik et al. 2019; van de Graaf et al. 2003).

Powdery scab and PMTV assessments. At harvest, all tubers from the middle two rows of each four-row plot were collected, field heatremoved, suberized, and stored at $12^{\circ} \mathrm{C}$ for a total of 100 days after harvest before retrieval of sample bags from storage for analysis. A subsample of 50 tubers from each plot was randomly chosen for evaluating powdery scab incidence and severity. Disease incidence was expressed as the percentage of infected tubers in the subsample, and disease severity was estimated according to a graphic scale provided by Falloon et al. (1995), where $0=$ no disease, $1=$ one pustule to $5 \%$ of tuber surface, and $2=5.1$ to $10,3=10.1$ to $15,4=15.1$ to $20,5=20.1$ to $33,6=33.1$ to $46,7=46.1$ to $60,8=60.1$ to $73,9=$ 73.1 to 86 , and $10=86.1$ to $100 \%$ of tuber surface). Of the 50 rated tubers from each plot, 10 tubers with powdery scab symptoms were cut into chips for assessment of necrosis symptoms. If fewer than 10 tubers had powdery scab symptoms, additional tubers were chosen from each plot until the sample size reached 10 tubers and the 10 total

Table 2. Mean incidence (\%) of powdery scab (PS) and potato mop-top virus (PMTV) in 10-tuber subsamples

\begin{tabular}{|c|c|c|c|c|c|}
\hline Farm, cultivar & Treatment & Tubers with PS & PMTV incidence with PS & Tubers without PS & PMTV incidence without PS \\
\hline \multicolumn{6}{|l|}{ Farm B } \\
\hline \multirow[t]{3}{*}{ Russet Norkotah line 8} & Omega & 33.3 & 20 & 66.7 & 26.7 \\
\hline & RIDEZ & 0 & 0 & 100 & 10 \\
\hline & Control & 6.67 & 0 & 93.3 & 50 \\
\hline \multirow[t]{3}{*}{ Canela Russet } & Omega & 0 & 0 & 100 & 80 \\
\hline & RIDEZ & 33.3 & 44.3 & 66.7 & 44.5 \\
\hline & Control & 6.67 & 60 & 93.3 & 50 \\
\hline \multirow[t]{3}{*}{ Ciklamen } & Omega & 33.3 & 30 & 66.7 & 53.3 \\
\hline & RIDEZ & 6.67 & 0 & 93.3 & 30 \\
\hline & Control & 40 & 13.3 & 60 & 25 \\
\hline \multirow[t]{3}{*}{ Modoc } & Omega & 53.3 & 66.7 & 80 & 70 \\
\hline & RIDEZ & 0 & 0 & 100 & 53.3 \\
\hline & Control & 73.3 & 23.3 & 26.7 & 0 \\
\hline \multirow[t]{3}{*}{ Satina } & Omega & 70 & 53.7 & 30 & 66.7 \\
\hline & RIDEZ & 46.7 & 33.3 & 53.3 & 86.7 \\
\hline & Control & 60 & 23.3 & 40 & 17.8 \\
\hline \multirow[t]{3}{*}{ Soraya } & Omega & 53.3 & 66.7 & 46.7 & 55.7 \\
\hline & RIDEZ & 60 & 60 & 40 & 60 \\
\hline & Control & 83.3 & 46.7 & 16.7 & 20 \\
\hline \multicolumn{6}{|l|}{ Farm C } \\
\hline \multirow[t]{3}{*}{ Russet Norkotah line 8} & Omega & 3.3 & 0 & 96.7 & 13.3 \\
\hline & RIDEZ & 0 & 0 & 100 & 20 \\
\hline & Control & 0 & 0 & 100 & 46.7 \\
\hline \multirow[t]{3}{*}{ Canela Russet } & Omega & 0 & 0 & 100 & 23.3 \\
\hline & RIDEZ & 3.3 & 33.3 & 96.7 & 55.2 \\
\hline & Control & 0 & 0 & 100 & 40 \\
\hline \multirow[t]{3}{*}{ Ciklamen } & Omega & 100 & 100 & 0 & 0 \\
\hline & RIDEZ & 100 & 73.3 & 0 & 0 \\
\hline & Control & 100 & 86.6 & 0 & 0 \\
\hline \multirow[t]{3}{*}{ Modoc } & Omega & 100 & 100 & 0 & 0 \\
\hline & RIDEZ & 100 & 100 & 0 & 0 \\
\hline & Control & 100 & 100 & 0 & 0 \\
\hline \multirow[t]{3}{*}{ Satina } & Omega & 100 & 73.3 & 0 & 0 \\
\hline & RIDEZ & 100 & 86.6 & 0 & 0 \\
\hline & Control & 100 & 73.3 & 0 & 0 \\
\hline \multirow[t]{3}{*}{ Soraya } & Omega & 70 & 54.8 & 30 & 58.3 \\
\hline & RIDEZ & 100 & 80 & 0 & 33.3 \\
\hline & Control & 73.3 & 70.5 & 26.7 & 42.2 \\
\hline
\end{tabular}


tubers were assayed for PMTV. This biased sampling for PMTV was used to determine whether PMTV can be detected in tubers with powdery scab and to determine whether there were associations between PMTV and powdery scab symptoms on tubers. Bud end and stem end slices were collected and stored at $4^{\circ} \mathrm{C}$ until further PMTV detection. PMTV presence was detected with an enzyme-linked immunosorbent assay (ELISA) using the PMTV Complete kit 960 (BIOREBA AG, Reinach, Switzerland).

Greenhouse experiments. Experimental design. S. subterranea inoculum was obtained from powdery scab lesions on Soraya tubers grown in field plots in the SLV in 2017. Sporosori were scraped off tuber lesions, separated from large soil particles and tuber skin pieces by sieving through 150 - and $75-\mu \mathrm{m}$ mesh sieves, and air dried before storing at $4{ }^{\circ} \mathrm{C}$. Sporosori ( 1 to $5 \mathrm{mg}$ ) were then suspended in water and the number of sporosori was determined with a hemocytometer (Baldwin et al. 2008, van de Graaf et al. 2005). Experiments were conducted from 27 March to 24 July 2018 (cultivar Satina) and 5 February to 7 May 2019 (cultivar Diplomat). In each trial, two potting mixes were prepared: PM1 $=1: 1: 2$ vermiculite (Sun Gro, Agwam, MA, U.S.A.)/peat moss (Berger, Saint-Modeste, QC, Canada)/sand and PM2 = 2:2 Fafard 4 P.M.ix (Sun Gro, Agawam, MA, U.S.A.)/sand. In total, 100 plants were used. Each component

Table 3. Type III tests of fixed effects for generalized linear mixed models relating to powdery scab (PS) incidence and severity, Spongospora subterranea soil inoculum, and potato mop-top virus (PMTV) incidence in field trials (2017 to 2018)

\begin{tabular}{|c|c|c|c|}
\hline Effect & df & $F$ value & $P$ value \\
\hline \multicolumn{4}{|l|}{ PS incidence } \\
\hline Chemical treatment & 2 & 0.07 & 0.94 \\
\hline Cultivar & 5 & 85.22 & $<0.01 * *$ \\
\hline Study site & 2 & 430.34 & $<0.01^{* *}$ \\
\hline Cultivar $\times$ study site & 10 & 70.76 & $<0.01 * *$ \\
\hline \multicolumn{4}{|l|}{ PS severity } \\
\hline Chemical treatment & 2 & 0.64 & 0.53 \\
\hline Cultivar & 5 & 31.85 & $<0.01 * *$ \\
\hline Study site & 2 & 108.10 & $<0.01 * *$ \\
\hline Cultivar $\times$ study site & 10 & 9.85 & $<0.01 * *$ \\
\hline \multicolumn{4}{|l|}{ S. subterranea inoculum } \\
\hline Chemical treatment & 2 & 4.33 & $0.02 * *$ \\
\hline Cultivar & 5 & 2.83 & $0.02 * *$ \\
\hline Study site & 2 & 6.27 & $<0.01 * *$ \\
\hline Chemical treatment $\times$ cultivar & 10 & 1.32 & 0.23 \\
\hline Chemical treatment $\times$ study site & 4 & 0.94 & 0.45 \\
\hline Cultivar $\times$ study site & 10 & 2.85 & $0.004 * *$ \\
\hline Chemical treatment $\times$ cultivar $\times$ study site & 20 & 0.90 & 0.58 \\
\hline
\end{tabular}

a Asterisks (**) indicate $P<0.01$. of the potting mixes was tested by qPCR to determine whether $S$. $s u b$ terranea could be detected prior to inoculation. Four inoculum levels- $-\mathrm{I} 0=$ noninoculated control and inoculum level 1 (I1) = 1 $\mathrm{sp} / \mathrm{g}, \mathrm{I} 2=5 \mathrm{sp} / \mathrm{g}, \mathrm{I} 3=10 \mathrm{sp} / \mathrm{g}$ of potting mix —and two chemicals (Omega at $2.35 \mu \mathrm{l} /$ pot or RIDEZ, which is equivalent to 3,508 $\mathrm{ml} / \mathrm{ha}$ ) with a nontreated control treatment were evaluated using an RCBD with five replicates.

Before planting, seed tubers (cultivar Satina) or minitubers (cultivar Diplomat) were sterilized in an approximately $0.8 \%$ solution of sodium hypochlorite. For Satina seed tubers, a melon scoop was used to remove individual bud regions (Houser and Davidson 2010). Each potting mix type was weighed to determine the amount of inoculum needed for each pot. The appropriate amounts of inoculum were then mixed into each potting mix depending on the required inoculum level. After filling each pot with prepared potting mix, each bud region or minituber was planted $5 \mathrm{~cm}$ below the surface level of potting mix. Omega or RIDEZ were immediately applied to each pot followed by watering to saturation using approximately $500 \mathrm{ml}$ of water. Each pot was irrigated by hand for 24 days after planting (DAP). Then, a drip system with 0.5 gallons/h (GPH) pressure pinch drip emitters (DripWorks, Willits, CA, U.S.A.) was installed in each pot to automatically apply water for 2 min every $8 \mathrm{~h}$. At approximately $75 \mathrm{DAP}$, the drip system was adjusted to apply water for 5 min every $8 \mathrm{~h}$ until harvest. In addition, each pot was fertilized individually with the same amount (nitrogen at $200 \mathrm{ppm} / \mathrm{pot}$ ) of the water-soluble fertilizer Peter's Blossom 10-30-20 (Peters Professional, Earth City, MO, U.S.A.) at around $35 \mathrm{DAP}$ on a 7-day schedule until harvest. The temperature in the greenhouse was set to 10 to $15.5^{\circ} \mathrm{C}$ with $70 \%$ relative humidity and a 12-h daylight setting.

Sampling and disease assessment. At approximately 120 DAP, roots, tubers, and a sample of the potting mixes were collected from each pot for disease assessment. Roots of individual plants were cut, placed into a resealable plastic bag, and transferred to the laboratory to remove excess soil. The number of root galls per plant was counted, after which roots were dried in an oven at $40^{\circ} \mathrm{C}$ for 2 days to obtain the dry root weight. Tubers were scored for powdery scab severity (Falloon et al. 1995) and incidence of powdery scab on tubers from each plant were recorded. Tubers harvested from each plant were cut into chips and assessed for necrotic symptoms. Slices from the bud end and the stem end were pooled together and used to determine PMTV infection using ELISA. DNA from $0.25 \mathrm{~g}$ per potting mix was extracted and the postharvest inoculum level of $S$. subterranea in each pot was determined by qPCR as described above.

Statistical analyses. Because the response variables were not normally distributed, generalized linear mixed models (GLMMs) were used to evaluate how powdery scab incidence and severity vary as functions of cultivar, fungicide treatment, study site, and the interaction of cultivar and study sites. Least squares means (LS-means) for chemical treatments were compared with the control, while
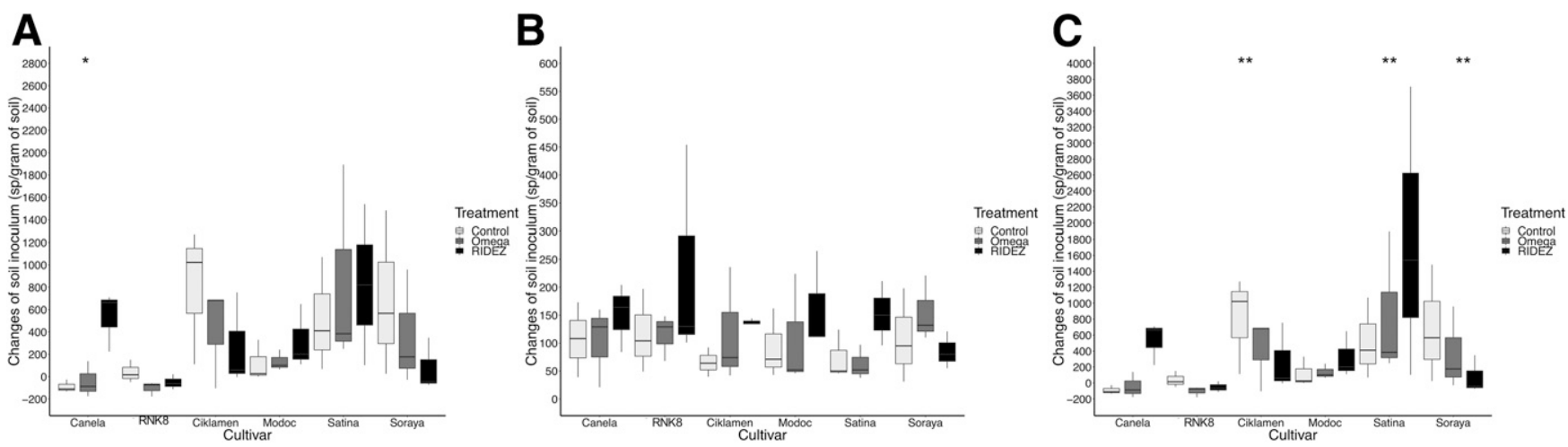

Fig. 2. Box plots of changes in Spongospora subterranea soil inoculum (sporosori [sp] per gram of soil) at planting and at harvest for each chemical treatment and cultivar at A, farm A; B, farm B; and C, farm C in San Luis Valley, Colorado during 2017 and 2018. Asterisks indicate a significant increase in soil inoculum change in a cultivar at a specific farm ( ${ }^{*}$ and ** indicate $P<0.05$ and 0.01 , respectively). RNK8 = Russet Norkotah line 8. 
LS-means for cultivars, study sites, and their interaction were compared using the Tukey method with step-down procedures for comparisons (LSMEANS).

To investigate the effect of chemical treatment on S. subterranea soil inoculum and the effect of cultivar on $S$. subterranea soil inoculum change, we used GLMMs where cultivar, study sites, chemical treatment, and their interactions were considered fixed effects. The LS-means of variables determined to be significant in the mixed model were compared as described above. Spearman's rank-order correlation coefficients were calculated to assess the potential associations between soil inoculum changes and powdery scab incidence or severity by each variable (PROC CORR). A similar approach was used for statistical analysis of the data obtained from the greenhouse experiments. Briefly, GLMMs were performed to analyze treatment effects on response variables and Spearman's correlation coefficients were calculated to examine relationships among different measured variables.

All statistical analyses were performed at a significance level of $\alpha=0.05$ using the statistical software SAS university edition (https://www.sas.com/en_us/software/university-edition.html).

\section{Results}

Field experiments. Relationship between powdery scab and PMTV incidence. S. subterranea was detected in soil in all three fields but powdery scab was observed only at two of the study sites (farms B and C). Mean disease incidence ranged from 0 to $16 \%$ at farm $\mathrm{B}$ and 0 to $74 \%$ at farm $\mathrm{C}$ across potato cultivars, and the mean severity ranged from 0 to 1 at farm $\mathrm{B}$ and 0 to 2 at farm C (Fig. 1). PMTV was detected from tubers harvested at farms $\mathrm{B}$ and $\mathrm{C}$ with and without the presence of powdery scab lesions, and there was no obvious correlation between development of powdery scab symptoms and PMTV infection in tubers (Table 2). Powdery scab incidence was significantly correlated with disease severity across all three locations $(R=0.9705$, $P<0.01$ ), and positive associations were also identified between soil inoculum change and powdery scab incidence and severity $\quad\left(R_{\text {DiffInoculum LesionIncidence }}=0.3546, \quad P=0.01\right.$; $R_{\text {DiffInoculum } \sim \text { LesionSeverity }}=0.3112, P=0.02$ ).

Effects of chemical soil treatment on powdery scab and PMTV incidence, and on S. subterranea soil inoculum. Neither Omega nor RIDEZ significantly suppressed powdery scab incidence or severity when compared with the nontreated control (Table 3; Fig. 1). Because we did not detect PMTV in the first year of our experiment, we biased sampling toward tubers with powdery scab symptoms in the second year of this study to ensure that the tubers were from plants infected with $S$. subterranea and, furthermore, to determine whether these fields were suitable for future work with PMTV. As a result, we were unable to conduct statistical analyses to compare
A
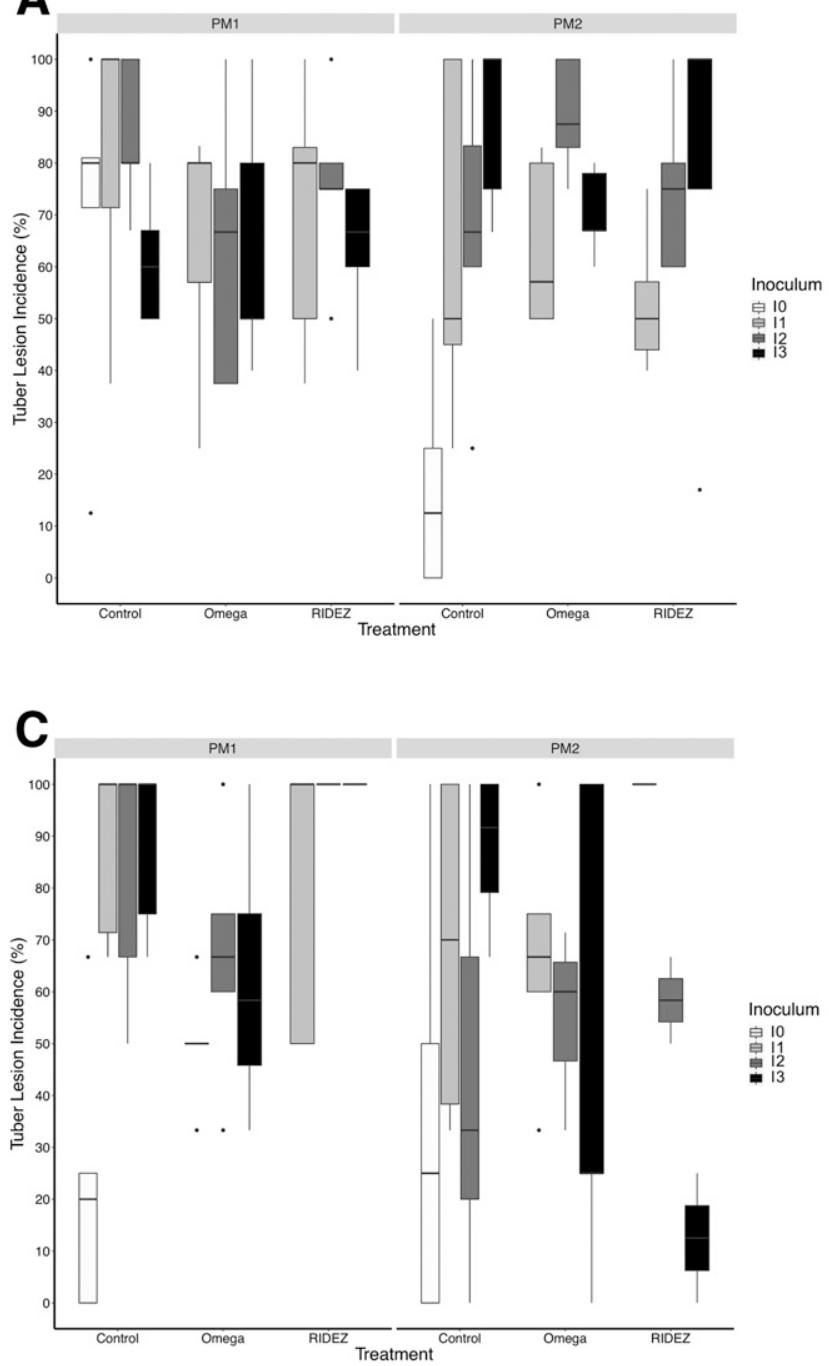

B

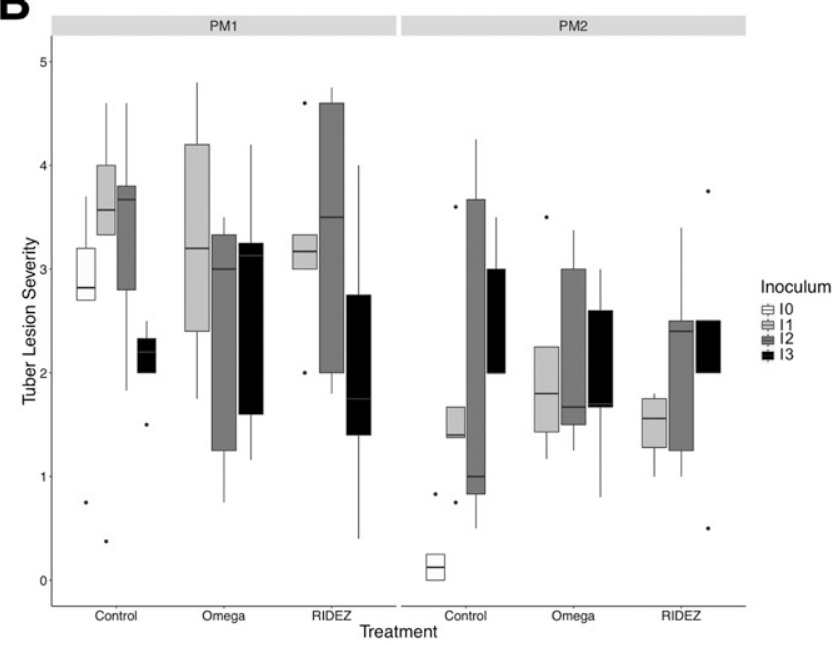

D

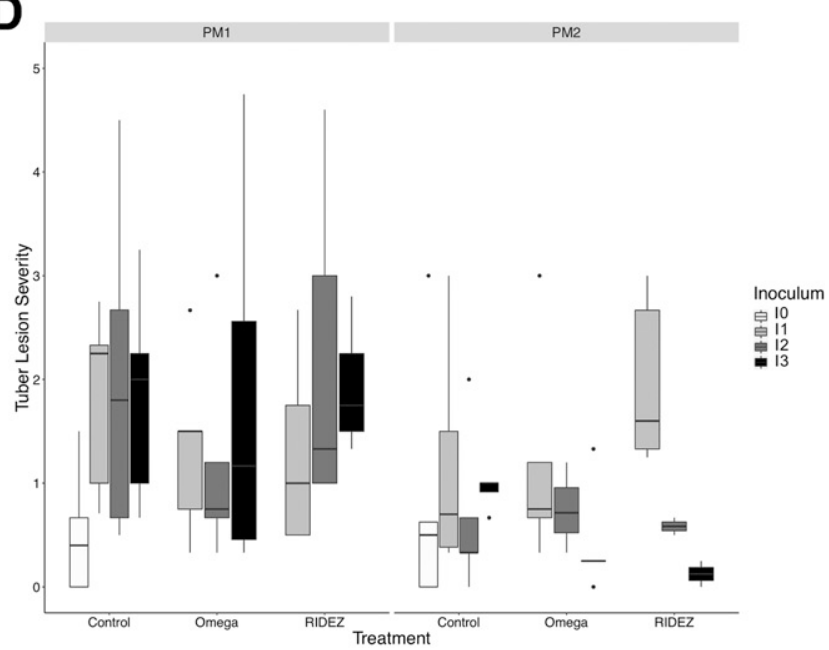

Fig. 3. Box plots of powdery scab incidence and severity on $\mathbf{A}$ and $\mathbf{B}$, Satina and $\mathbf{C}$ and $\mathbf{D}$, Diplomat in the greenhouse experiments. $10,11,12$, and $I 3$ represent $0,1,5$, and 10 sporosori/g of potting mix, respectively. 
chemical effects on PMTV incidence. However, our data do not show any trends suggesting that PMTV incidence was affected by chemical treatment at farms B and C (Table 2).

S. subterranea soil inoculum levels were significantly affected by chemical treatment, study site, and cultivar, and cultivars behaved differently at different study sites (Table 3). The mean inoculum levels were greater following a potato crop at all three locations $\left(P_{\text {FarmA }}=0.02 ; P_{\text {FarmB }}=0.03 ; P_{\text {FarmC }}<0.01\right)$ with changes ranging from -137 to $2,613,21$ to 454 , and -178 to $3,707 \mathrm{sp} / \mathrm{g}$ of soil and mean increases of 137, 119, and $368 \mathrm{sp} / \mathrm{g}$ of soil at farms A, B, and $\mathrm{C}$, respectively. Soil inoculum levels were significantly different among chemical treatments $(P=0.02)$ (Table 3$)$. The mean soil inoculum changes were 162,122 , and $340 \mathrm{sp} / \mathrm{g}$ of soil in the control, Omega-, and RIDEZ-treated plots, respectively. In-furrow treatment with Omega slightly decreased $S$. subterranea soil inoculum across all locations $\left(\right.$ mean $_{\text {Omega-Control }}=-39 \mathrm{sp} / \mathrm{g}$ of soil) but the effects were not significant $(P=0.62)$. In contrast, in-furrow application and foliar sprays of RIDEZ consistently increased the mean soil inoculum levels at all locations $(P=0.03)$. Although there were no overall effects of chemical treatment on soil inoculum changes when various potato cultivars were planted across farms (Table 3), application of RIDEZ increased the soil inoculum in Canela Russet (mean = $557 \mathrm{sp} / \mathrm{g})$, Ciklamen $($ mean $=291 \mathrm{sp} / \mathrm{g})$, and Satina plots $($ mean $=769$

Table 4. Type III tests of fixed effects for generalized linear mixed models relating to powdery scab (PS) incidence and severity, root gall formation, and Spongospora subterranea soil inoculum in greenhouse experiments (2017 to 2019$)^{\mathrm{a}}$

\begin{tabular}{|c|c|c|c|c|}
\hline $\begin{array}{l}\text { Cultivar, response } \\
\text { variable }\end{array}$ & Effect & df & $F$ value & $P>F$ \\
\hline \multicolumn{5}{|l|}{ Satina } \\
\hline \multirow[t]{4}{*}{ PS incidence } & Inoculum & 3 & 5.88 & $<0.01 * *$ \\
\hline & Potting mix & 1 & 5.11 & $0.03 *$ \\
\hline & Chemical & 2 & 0.57 & 0.57 \\
\hline & Inoculum $\times$ potting mix & 3 & 6.3 & $<0.01^{* *}$ \\
\hline \multirow[t]{4}{*}{ PS severity } & Inoculum & 3 & 2.83 & $0.04 *$ \\
\hline & Potting mix & 1 & 25.04 & $<0.01^{* *}$ \\
\hline & Chemical & 2 & 0.06 & 0.95 \\
\hline & Inoculum $\times$ potting mix & 3 & 3.86 & $0.01 *$ \\
\hline \multirow[t]{4}{*}{ Root gall formation } & Inoculum & 3 & 8.58 & $<0.01 * *$ \\
\hline & Potting mix & 1 & 12.01 & 0.20 \\
\hline & Chemical & 2 & 3.89 & $0.02 *$ \\
\hline & Inoculum $\times$ potting mix & 3 & 1.58 & 0.20 \\
\hline \multirow{5}{*}{$\begin{array}{l}\text { S. subterranea } \\
\text { inoculum }\end{array}$} & & 3 & 4.63 & $<0.01 * *$ \\
\hline & Inoculum & & & \\
\hline & Potting mix & 1 & 1.40 & 0.24 \\
\hline & Chemical & 2 & 4.20 & $0.02 *$ \\
\hline & Inoculum $\times$ potting mix & 3 & 1.24 & 0.30 \\
\hline \multicolumn{5}{|l|}{ Diplomat } \\
\hline \multirow{4}{*}{ PS incidence } & Inoculum & 3 & 7.78 & $<0.01 * *$ \\
\hline & Potting mix & 1 & 2.19 & 0.15 \\
\hline & Chemical & 2 & 5.22 & $<0.01^{* *}$ \\
\hline & Inoculum $\times$ potting mix & 3 & 3.39 & $0.02 *$ \\
\hline \multirow[t]{4}{*}{ PS severity } & Inoculum & 3 & 1.66 & 0.18 \\
\hline & Potting mix & 1 & 4.90 & $0.03^{*}$ \\
\hline & Chemical & 2 & 0.86 & 0.43 \\
\hline & Inoculum $\times$ potting mix & 3 & 2.90 & $0.04 *$ \\
\hline \multirow[t]{4}{*}{ Root gall formation } & Inoculum & 3 & 1.52 & $<0.01 * *$ \\
\hline & Potting mix & 1 & 0.07 & 0.80 \\
\hline & Chemical & 2 & 4.49 & $0.01 *$ \\
\hline & Inoculum $\times$ potting mix & 3 & 0.56 & 0.64 \\
\hline \multirow{5}{*}{$\begin{array}{l}\text { S. subterranea } \\
\text { inoculum }\end{array}$} & & 3 & 0.31 & 0.82 \\
\hline & Inoculum & & & \\
\hline & Potting mix & 1 & 1.19 & 0.28 \\
\hline & Chemical & 2 & 5.82 & $<0.01 * *$ \\
\hline & Inoculum $\times$ potting mix & 3 & 1.47 & 0.23 \\
\hline
\end{tabular}

a Asterisks * and $* *$ indicate $P<0.05$ and 0.01 , respectively. $\mathrm{sp} / \mathrm{g})(P$ all $<0.01)$. The increased soil inoculum after planting Satina was also correlated with the application of Omega $($ mean $=311 \mathrm{sp} / \mathrm{g}$, $P=0.0242$ ) (Fig. 2).

Responses of potato cultivars to powdery scab and PMTV across farms. Significant differences were observed in powdery scab incidence and severity among potato cultivars and locations with a significant cultivar-location interaction (Table 3; Fig. 1). Russetskinned cultivars (Canela Russet and Russet Norkotah) had the lowest mean disease incidences (both were $0.07 \%$ ) and their tubers were significantly more tolerant to powdery scab when compared with yellow-skinned $(P<0.01)$ and red-skinned $(P<0.01)$ cultivars (Fig. 1). The greatest incidence was observed on the yellow-skinned cultivar Satina $\left(\right.$ mean $=24.4 \%$; mean $_{\text {Satina-Russet }}$ Norkotah $=24.3 \%$, $P<0.01 ;$ mean $_{\text {Satina-Canela Russet }}=24.30 \%, P<0.01 ;$ mean $_{\text {Satina-Ciklamen }}=$ $12.6 \%, P<0.01 ;$ mean $_{\text {Satina-Modoc }}=9.3 \%, P<0.01 ;$ mean $_{\text {Satina-Soraya }}=$ $16.1 \%, P<0.01)$, followed by the red-skinned cultivars Modoc (mean $=$ $15.1 \%$; mean $_{\text {Modoc-Russet Norkotah }}=15 \%, P<0.01 ;$ mean $_{\text {Modoc-Canela Russet }}=$ $15 \%, P<0.01 ;$ mean $_{\text {Modoc-Ciklamen }}=3.3 \%, P<0.01 ;$ mean $_{\text {Modoc-Soraya }}=$ $6.8 \%, P<0.01)$ and Ciklamen (mean $=11.8 \%$; mean $_{\text {Ciklamen-Russet }}$ Norkotah $=11.7 \%, P<0.01 ;$ mean $_{\text {Modoc-Canela Russet }}=11.7 \%, P<0.01$; mean $\left._{\text {Ciklamen-Soraya }}=3.5 \%, P<0.01\right)$. The yellow-skinned cultivar Soraya had a mean incidence of $8.3 \%(P<0.01)$. Powdery scab severity was lowest in Canela Russet and Russet Norkotah (mean $=0.04$; mean $_{\text {Ciklamen-Russet Norkotah }}=0.56, P<0.01 ;$ mean $_{\text {Modoc-Russet Norkotah }}=$ $0.44, P<0.01 ;$ mean $_{\text {Satina-Russet Norkotah }}=0.78, P<0.01 ;$ mean $_{\text {Soraya-Canela }}$ Russet $=0.56, P<0.01 ;$ mean $_{\text {Modoc-Canela Russet }}=0.44, P<0.01$; mean $_{\text {Satina-Canela Russet }}=0.78, P<0.01 ;$ mean $_{\text {Soraya-Russet Norkotah }}=0.56$, $P<0.01)$ and highest in Satina (mean $=0.8$; mean $_{\text {Satina-Ciklamen }}=0.22$, $P<0.01 ;$ mean $_{\text {Satina-Modoc }}=0.33, P<0.01 ;$ mean $_{\text {Satina-Soraya }}=0.22$, $P<0.01)$. Severity was similar among Ciklamen (mean $=0.59)$, Modoc $($ mean $=0.48)$, and Soraya $($ mean $=0.59)($ Fig. 1$)$.

Mean powdery scab incidence and severity were significantly different among all three locations (Table 3), with the highest levels observed at farm $\mathrm{C}$, followed by farm $\mathrm{B}$ and farm $\mathrm{A}$ (incidence: mean $_{\text {FarmA-FarmB }}=-2.85 \%, P=0.01 ;$ mean $_{\text {FarmA-FarmC }}=-27 \%$, $P<0.01 ;$ mean $_{\text {FarmB-FarmC }}=-24.14 \%, P<0.01$; severity: mean $_{\text {FarmA-FarmB }}=-0.44, P<0.01 ;$ mean $_{\text {FarmA-FarmC }}=-0.8333$, $P<0.01 ;$ mean $_{\text {FarmB-FarmC }}=-0.3889 ; P<0.01$ ) (Fig. 1). Ciklamen, Modoc, Satina, and Soraya were susceptible to powdery scab, and higher powdery scab incidences were observed on Ciklamen and Modoc at farm $\mathrm{C}$ compared with farm B (mean ${ }_{\text {Modoc:Farm C-Modoc: }}$ FarmB $=42.4 \%, P<0.01 ;$ mean $_{\text {Ciklamen:FarmC-Ciklamen:FarmB }}=39.6 \%$, $P<0.01)$.

Tubers with and without powdery scab were assessed for PMTV and all cultivars were susceptible to the virus (Table 2). Russet Norkotah had the lowest PMTV incidence. With this cultivar, $3.4 \%$ of tubers with powdery scab and $27.8 \%$ of tubers without powdery scab were infected with PMTV. The greatest PMTV incidence was found on Soraya and the virus was detected in $63.1 \%$ of tubers with powdery scab and $56.1 \%$ of tubers without powdery scab. In addition, PMTV was detected in 57.3 and $28.5 \%$ of Satina tubers (with and without powdery scab, respectively), as well as 65 and $20.6 \%$ of Modoc tubers (with and without powdery scab, respectively).

$\mathrm{S}$. subterranea soil inoculum changed in response to different potato cultivars. Cultivar was an important factor that drove S. subterranea soil inoculum changes across farms whether or not tuber lesions were observed (Table 3; Fig. 2). For example, soil inoculum increased after planting Canela Russet (mean $=192 \mathrm{sp} / \mathrm{g}, P=0.02)$, Ciklamen $($ mean $=256 \mathrm{sp} / \mathrm{g}, P<0.01)$, Satina $($ mean $=440 \mathrm{sp} / \mathrm{g}, P<$ 0.01 ), and Soraya (mean $=185 \mathrm{sp} / \mathrm{g}, P=0.02$ ); however, only Satina had a high incidence of powdery scab. Neither Canela Russet nor Russet Norkotah had a high incidence of powdery scab but soil inoculum was not significantly increased after planting Russet Norkotah (mean $=57 \mathrm{sp} / \mathrm{g}, P=0.47$ ).

When comparing cultivar and study site interactions on soil inoculum changes, Canela Russet planted at farm A (mean $=323$ sp/g, $P=0.02)$ as well as Ciklamen, Satina, and Soraya planted at farm C $\left(\right.$ mean $_{\text {Ciklamen }}=498 \mathrm{sp} / \mathrm{g}, P<0.01 ;$ mean $_{\text {Satina }}=1,047 \mathrm{sp} / \mathrm{g}$, $P<0.01 ;$ mean $\left._{\text {Soraya }}=379 \mathrm{sp} / \mathrm{g}, P<0.01\right)($ Table 3 ; Fig. 2) 
significantly increased soil inoculum levels. In addition, Satina at farm $\mathrm{C}$ had the highest change in soil inoculum (Fig. 2C), although there were no significant differences between soil inoculum changes at farms $\mathrm{A}$ and $\mathrm{B}$ after planting Satina $\left(\right.$ mean $_{\text {Satina } \times \text { FarmA }}=$ $175 \mathrm{sp} / \mathrm{g}, P=0.20$, mean ${ }_{\text {Satina } \times \text { FarmB }}=96 \mathrm{sp} / \mathrm{g}, P=0.48$ ) (Fig. $2 \mathrm{~A}$ and B).

Greenhouse experiments. Powdery scab, root gall formation, and PMTV. The mean incidence of powdery scab on Satina tubers grown in PM1 and PM2 ranged from 12.5 to $100 \%$ with a mean of $68.9 \%$ and 0 to $100 \%$ with a mean of $57.6 \%$, respectively (Fig. 3A). Tuber lesions on Satina tubers grown in PM1 were more severe than those grown in PM2 (0.375 to 4.8 with a mean of 2.77 in PM1 and 0 to 4.25 with a mean of 1.57 in PM2; mean $_{\mathrm{PM} 1-\mathrm{PM} 2}=1.20, P<$ 0.01 ) (Fig. 3B), and powdery scab symptoms were significantly more severe only when the potting mixes were inoculated with sporosori at $5 \mathrm{sp} / \mathrm{g}$ and compared with the noninoculated control $\left(\right.$ mean $_{\mathrm{I} 1-\mathrm{I} 0}=$ $1.10, P=0.05 ;$ mean $_{\mathrm{I} 2-\mathrm{I} 0}=1.18, P=0.03 ;$ mean $_{\mathrm{I} 3-\mathrm{I} 0}=0.87, P=$ $0.17)$. Powdery scab incidence and severity on Satina in noninoculated PM1 were similar to potting mixes inoculated with all three levels of inoculum. As in the field trials, neither Omega nor RIDEZ treatments reduced powdery scab expression on Satina in the greenhouse trial (Table 4; Fig. 3A).

Unlike Satina, the mean incidence of powdery scab on Diplomat in PM1 was similar to the mean incidence in PM2 (22.3 to $100 \%$ with a mean of $64.4 \%$ in PM1 and 12.5 to $100 \%$ with a mean of $54.9 \%$ in PM2; mean $_{\mathrm{PM} 1-\mathrm{PM} 2}=9.51 \%, P=0.14$ ) (Fig. 3C). However, the mean tuber lesion severity on Diplomat was higher in PM1 than in PM2 (0.51 to 2.19 with a mean of 1.6 in PM1 and 0.42 to 1.97 with a mean of 0.86 in PM2; mean $_{\mathrm{PM} 1-\mathrm{PM} 2}=0.53$, $P=0.03$ ) (Fig. 3D). More tubers were observed with powdery scab lesions in the inoculated treatments (Table 4; Fig. 3C); however, no significant differences were observed in lesion severity among the various inoculum levels, although powdery scab was more severe in the 5 - and $10-\mathrm{sp} / \mathrm{g}$ treatments $(P<0.05)$ (Table 4; Fig. 3D). We observed a reduction of powdery scab incidence on Diplomat when Omega was applied $\left(\right.$ mean $_{\text {Control-Omega }}=18.72 \%, P=$ 0.04) (Table 4; Fig. 3C). Similar to the field experiments, RIDEZ had no effect on either tuber lesion incidence or severity (incidence: mean $_{\text {Control-RIDEZ }}=-4.63 \%, P=0.55$; severity: mean $_{\text {Control-RIDEZ }}=$ $-0.01, P=0.97)$.

Both Satina and Diplomat were susceptible to root gall formation. The mean number of root galls per gram of dry root varied among treatments and ranged from 3 to 880 on Satina and 84 to 1,335 on
Diplomat (Fig. 4). RIDEZ significantly increased the number of root galls per gram of dry root (Satina: mean $_{\text {RIDEZ-Control }}=93, P=0.03$; Diplomat: mean $_{\text {RIDEZ-Control }}=92, P=0.03$ ) but there was no difference between the control and the Omega treatment (Satina: mean $_{\text {Omega-Control }}=17, P=0.64$; Diplomat: mean $_{\text {Omega-Control }}=16$, $P=0.63$ ) (Table 4). The mean number of root galls per gram of dry root on Satina increased with an increasing amount of $S$. subterranea inoculum when compared with the noninoculated control but no differences were found on Diplomat root gall formation (root galls per gram of dry root) among inoculum levels (Satina: mean $_{\mathrm{I} 0}=69, P=0.15$; mean $_{\mathrm{I} 1}=126, P<0.01 ;$ mean $_{\mathrm{I} 2}=250, P<0.01 ;$ mean $_{\mathrm{I} 3}=259, P<$ 0.01; Diplomat: mean $_{\mathrm{I} 0}=335 ;$ mean $_{\mathrm{I} 1}=346$, mean $_{\mathrm{I} 2}=409$, mean $_{\mathrm{I} 3}=$ 471; all $P>0.76$ ) (Fig. 4).

PMTV incidence ranged from 60 to $100 \%$ with a mean of $93 \%$ on Satina and a mean of $87 \%$ on Diplomat. PMTV was also detected in Satina and Diplomat daughter tubers harvested from noninoculated controls of both potting mix types. Neither RIDEZ nor Omega treatments reduced PMTV incidence (Table 5).

Postharvest S. subterranea soil inoculum. Significant variation was observed in postharvest $S$. subterranea inoculum levels among treatments in the Satina greenhouse trial (Fig. 5A). Although preplant inoculum was below the limit of detection by qPCR in noninoculated pots, the mean postharvest levels ranged from 1,204 to $34,285 \mathrm{sp} / \mathrm{g}$ of potting mix in PM1 and 292 to 18,445 sp/g of potting mix in PM2. Under optimum conditions, postharvest inoculum increased significantly in pots with a known amount of inoculum added when compared with the postharvest inoculum detected in noninoculated pots $\left(\right.$ mean $_{\mathrm{I} 1-\mathrm{I} 0}=51,854 \mathrm{sp} / \mathrm{g}, P=0.04 ;$ mean $_{\mathrm{I} 2-\mathrm{I} 0}=65,622 \mathrm{sp} / \mathrm{g}$, $P<0.01 ;$ mean $_{\mathrm{I}-\mathrm{I} 0}=66,117 \mathrm{sp} / \mathrm{g}, P<0.01$ ) (Table 4; Fig. 5A). Chemical treatment also played a role in increasing postharvest inoculum level, which was shown by higher inoculum levels determined in pots treated with RIDEZ $\left(\right.$ mean $_{\text {RIDEZ-Omega }}=35,710 \mathrm{sp} / \mathrm{g}, P=$ 0.01) (Table 4). Similar to the results observed in the field trials, Omega reduced postharvest inoculum levels when compared with the nontreated control; however, the effect was not significant $\left(\right.$ mean $\left._{\text {Omega-Control }}=-14,346 \mathrm{sp} / \mathrm{g}, P=0.25\right)$. Conversely, postharvest $S$. subterranea inoculum levels only differed between chemical treatments in the Diplomat greenhouse trial (Table 4). Mean postharvest inoculum was determined as $2,517 \mathrm{sp} / \mathrm{g}$ (263 to 8,383 $\mathrm{sp} / \mathrm{g}$ ) in control pots, while the postharvest inoculum was 1,005 sp/g $\left(146\right.$ to $7,634 \mathrm{sp} / \mathrm{g}$; mean $\left._{\text {Control-Omega }}=1,512 \mathrm{sp} / \mathrm{g}, P<0.01\right)$ and $1,722 \mathrm{sp} / \mathrm{g}\left(243\right.$ to $6,324 \mathrm{sp} / \mathrm{g} ;$ mean $_{\text {Control-RIDEZ }}=795 \mathrm{sp} / \mathrm{g}$, $P=0.21)$ in Omega- and RIDEZ-treated pots, respectively,
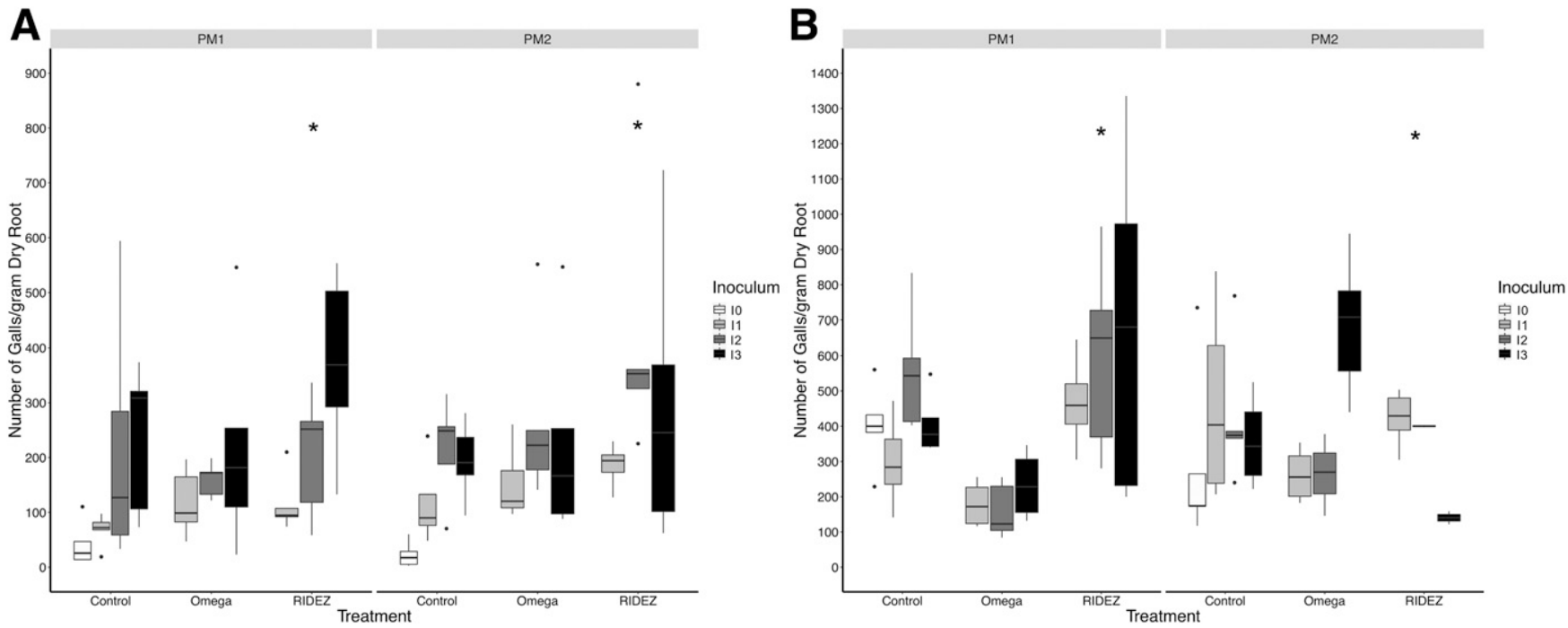

Fig. 4. Box plots of root galls per gram of dry root among different treatments on A, Satina and B, Diplomat in the greenhouse experiments. An asterisk $\left({ }^{*}\right)$ indicates that a significant difference was observed in a chemical treatment $(P<0.05)$. 10, I1, I2, and I3 represent $0,1,5$, and 10 sporosori/g of potting mix, respectively. 
indicating an inhibitory effect of Omega on sporosorus inoculum amounts when compared with the control.

The relationship of powdery scab, root gall formation, and postharvest $\mathrm{S}$. subterranea inoculum. A positive correlation was observed between powdery scab incidence and tuber lesion severity on Satina and Diploma in the greenhouse experiments $\left(R_{\text {Satina }}=0.6304, P<\right.$ $\left.0.01 ; R_{\text {Diplomat }}=0.7992, P<0.01\right)$. Postharvest $S$. subterranea inoculum was only correlated with the number of root galls per gram of dry root in the Satina trial $(R=0.4249, P<0.01)$. In contrast, powdery scab incidence, severity, and root gall formation were all positively correlated to postharvest inoculum level in the Diplomat trial $\left(R_{\text {inoculum } \sim \text { severity }}=0.2201, P=0,04 ; R_{\text {inoculum } \sim \text { incidence }}=0.2510\right.$, $\left.P=0.02 ; R_{\text {inoculum } \sim \text { root gall formation }}=0.2141, P=0.048\right)$.

Table 5. Potato mop-top virus (PMTV) incidence in tuber samples collected in the greenhouse experiments

\begin{tabular}{|c|c|c|}
\hline $\begin{array}{l}\text { Cultivar, potting mix, inoculum } \\
\text { level }^{\mathbf{a}}\end{array}$ & $\begin{array}{l}\text { Chemical } \\
\text { treatment }\end{array}$ & $\begin{array}{l}\text { PMTV incidence } \\
(\%)^{\mathbf{b}}\end{array}$ \\
\hline \multicolumn{3}{|l|}{ Satina } \\
\hline \multicolumn{3}{|l|}{ PM1 } \\
\hline I0 & Control & 80 \\
\hline \multirow[t]{3}{*}{ I1 } & Omega & 100 \\
\hline & RIDEZ & 80 \\
\hline & Control & 100 \\
\hline \multirow[t]{3}{*}{$\mathrm{I} 2$} & Omega & 100 \\
\hline & RIDEZ & 100 \\
\hline & Control & 100 \\
\hline \multirow[t]{3}{*}{ I3 } & Omega & 100 \\
\hline & RIDEZ & 80 \\
\hline & Control & 100 \\
\hline \multicolumn{3}{|l|}{ PM2 } \\
\hline I0 & Control & 100 \\
\hline \multirow[t]{3}{*}{ I1 } & Omega & 100 \\
\hline & RIDEZ & 100 \\
\hline & Control & 100 \\
\hline \multirow[t]{3}{*}{ I2 } & Omega & 80 \\
\hline & RIDEZ & 60 \\
\hline & Control & 100 \\
\hline \multirow[t]{3}{*}{$\mathrm{I} 3$} & Omega & 100 \\
\hline & RIDEZ & 100 \\
\hline & Control & 80 \\
\hline \multicolumn{3}{|l|}{ Diplomat } \\
\hline \multicolumn{3}{|l|}{ PM1 } \\
\hline I0 & Control & 60 \\
\hline \multirow[t]{3}{*}{ I1 } & Omega & 80 \\
\hline & RIDEZ & 60 \\
\hline & Control & 100 \\
\hline \multirow[t]{3}{*}{ I2 } & Omega & 80 \\
\hline & RIDEZ & 100 \\
\hline & Control & 100 \\
\hline \multirow[t]{3}{*}{$\mathrm{I} 3$} & Omega & 60 \\
\hline & RIDEZ & 100 \\
\hline & Control & 100 \\
\hline \multicolumn{3}{|l|}{ PM2 } \\
\hline I0 & Control & 60 \\
\hline \multirow{3}{*}{ I1 } & Omega & 100 \\
\hline & RIDEZ & 100 \\
\hline & Control & 100 \\
\hline \multirow[t]{3}{*}{ I 2} & Omega & 100 \\
\hline & RIDEZ & 100 \\
\hline & Control & 100 \\
\hline \multirow[t]{3}{*}{$\mathrm{I} 3$} & Omega & 80 \\
\hline & RIDEZ & 100 \\
\hline & Control & 60 \\
\hline
\end{tabular}

a PM1 and PM2 = two potting mixes and I0, I1, I2, and $\mathrm{I} 3$ represent $0,1,5$, and 10 sporosori/g of potting mix, respectively.

b Five plants per treatment.

\section{Discussion}

This study demonstrated that neither RIDEZ nor Omega are effective in reducing powdery scab incidence and severity in field or greenhouse trials. Treatment with RIDEZ increased root gall formation and postharvest soil inoculum under optimum greenhouse conditions for the pathogen, and it increased variability in soil inoculum levels in the field. Postharvest soil inoculum levels in field plots treated with Omega were lower than control plots and this effect was also seen in one of the two greenhouse trials. Neither the RIDEZ nor Omega treatments reduced the incidence of PMTV in any of the trials.

To our knowledge, this is the first report of the effects of the biological extract RIDEZ on $S$. subterranea soil inoculum levels and powdery scab control. The RIDEZ treatments were correlated with increases in postharvest $S$. subterranea soil inoculum. A previous study reported that increased use of fertilizers containing nitrate or ammonium increased powdery scab (Shah et al. 2014). However, the difference in postharvest inoculum increase between the RIDEZ and control plots was 500-fold or more with some cultivars in the present study. This suggests that RIDEZ promoted root infection by $S$. subterranea through effects on the pathogen, the plant, or the potato rhizobiome. Thus, future studies could determine which compound in RIDEZ actually promoted root galling, and understanding this mechanism could help in developing methods to inhibit $S$. subterranea inoculum production. Fluazinam (Omega) has been previously evaluated and results have been conflicting, indicating inconsistencies in its effects for reducing powdery scab (Braithwaite et al. 1994; Merz and Falloon 2009; Thangavel et al. 2015; Tsror (Lahkim) et al. 2019, 2020). Although partially effective, fluazinam and other soil treatments are costly and can have negative environmental effects (Merz and Falloon 2009; Simango and van der Waals 2017; Tsror (Lahkim) et al. 2019, 2020).

We evaluated the responses of six potato cultivars to powdery scab, S. subterranea, and PMTV. Overall, yellow-skinned Satina had the most severe powdery scab, whereas russet-skinned Canela and Russet Norkotah had minimal disease across study sites. However, the changes we observed in soil inoculum levels suggest that roots of Canela Russet may have been infected by S. subterranea. For example, planting Canela with RIDEZ treatment on farms A and $\mathrm{C}$ resulted in inoculum level increases comparable with those produced by the red- and yellow-skinned cultivars. In contrast, soil inoculum was reduced on farms A and C after planting Russet Norkotah under the RIDEZ treatment, indicating that Russet Norkotah could be recommended as an alternative russet-skinned cultivar for planting in S. subterranea-infested fields. Currently, potato growers prefer to grow russet-skinned cultivars to mitigate losses due to powdery scab if $S$. subterranea is present at high levels in their fields. Nevertheless, tuber-phase-tolerant cultivars (i.e., russet-skinned) may contribute to soil health degradation because they still contribute to increasing soil inoculum and disease pressure of this plasmodiophorid pathogen due to their root susceptibility to S. subterranea. Like other significant soilborne pathogens such as the potato cyst nematode (Globodera sp.), once S. subterranea is established in soil, management options are limited to planting nonhost rotation crops or $S$. subterranea-resistant potato lines to reduce soil inoculum (Dandurand et al. 2019). Previous studies have found that the incidence and severity of tuber symptoms are not directly correlated with root gall formation (Bittara et al. 2016; Falloon et al. 2003, 2016), and that root galls play an important role in the disease cycle and inoculum production because resting spores can be released back to the soil as new primary sources of inoculum when root galls decay (Balendres 2017; Merz 2008). The changes in soil inoculum levels in our field experiments suggest that S. subterranea was completing its life cycle and multiplying in all the evaluated potato cultivars, likely in root galls. The positive correlations between root gall number and postharvest inoculum levels in the greenhouse trials also provide evidence that root gall formation contributes to increasing $S$. subterranea inoculum.

Previous studies reported no correlations between powdery scab on tubers and incidence of PMTV-induced tuber necrosis (Kirk 2008; 
Montero-Astúa et al. 2008; Tenorio et al. 2006). In addition to detecting PMTV in tubers with powdery scab lesions, we also found a high percentage of tubers that lacked powdery scab but were infected with PMTV. Because PMTV is vectored by $S$. subterranea zoospores and these zoospores can infect potato root, stolon, and tuber surfaces, it is not surprising to find tubers free of powdery scab that are infected with PMTV. The russet cultivars Canela and Russet Norkotah had the least powdery scab incidence (not exceeding 3\%), and yet PMTV incidence surpassed 30\% in most plots with these cultivars. This supports previous reports that root or stolon infection plays an important role in virus transmission (Tenorio et al. 2006), and examination of root infection may indicate PMTV resistance, especially for potato breeding purposes.

Initial inoculum and environmental factors, such as soil water and drainage, irrigation and precipitation, soil texture, $\mathrm{pH}$, and temperature, are all associated with powdery scab occurrence and severity (Bittara 2015; Falloon 2008; Harrison et al. 1997; Merz and Falloon 2009; van de Graaf et al. 2005, 2007). Of these factors, soil water and drainage, and the intensity and duration of irrigation and precipitation, have a significant effect on powdery scab development, because these determine water availability for host plants and the pathogen (van de Graaf et al. 2005; Wale 2000). In the present study, we found that farm A had a higher preplant inoculum level than farm B yet no disease occurred on farm A. In contrast, the mean powdery scab incidences at farm $\mathrm{B}$ ranged from 0 to $16 \%$ across potato cultivars. The amount of irrigation, including precipitation water, at farm B was twice that at farm A. It is highly likely that powdery scab occurrence was driven by irrigation because the amount of water present in the soil is essential for $S$. subterranea zoospores to move and attach to plant tissue and initiate infections. These results also agree with previous studies demonstrating that high soil water content is correlated with high disease incidence and more severe powdery scab (Harrison et al. 1997; Merz and Falloon 2009). Initial inoculum concentration before planting was thought to be the major factor positively correlated with powdery scab severity. Under favorable conditions (farm B), a low amount of inoculum can result in severe disease in susceptible cultivars whereas, under suboptimum conditions (farm A), the role of initial inoculum may be minor (Brierley et al. 2013; Merz et al. 2012; Nakayama et al. 2007; Qu et al. 2006). However, our study reported that inoculum level increased by the end of the growing season, even when tuber disease did not occur, perhaps due to pathogen multiplication on plant roots or stolons. Therefore, it appears that, with current strategies, each crop of potato decreases soil health in S. subterranea-infested fields due to accumulation of this plasmodiophorid pathogen and the virus it carries.

qPCR was performed to determine whether each component of potting mix in the greenhouse trials was free of $S$. subterranea. The qPCR results indicated that the materials were not infested with $S$. subterranea, and yet severe powdery scab symptoms and high PMTV incidences were found on Satina and Diplomat grown in noninoculated mixes (negative controls). Peat-based potting mix was previously considered to be free of potato pathogens. In 2006, a potato minituber production facility in South Africa had an outbreak of powdery scab and the $S$. subterranea contamination was most likely introduced through coconut peat (Wright et al. 2012). In addition, growers in multiple states of the United States recently reported powdery scab symptoms on tubers grown in peat-based potting mix (Mallik et al. 2019). Peat-based potting mix is commonly used to grow ornamental plants and is used in the initial steps of seed potato production in greenhouses (Awati et al. 2019). Considering the broad host range of $S$. subterranea, our findings suggest that potting mix could contribute to the spread of $S$. subterranea and PMTV in the United States and that it could impact plant research and production of other plant species. Thus, developing an improved detection method for S. subterranea in peat-based potting mix is an urgent need to prevent the spread of both pathogens.

In conclusion, Omega and RIDEZ did not suppress powdery scab or PMTV infection in our field and greenhouse studies. S. subterranea soil inoculum in fields increased by the end of the growing season, even when no powdery scab lesions were found on tubers. Therefore, developing potato cultivars with root disease resistance is important for improving crop and soil health. Powdery scab occurrence and severity were influenced by cultivar, environment, and on-farm management practices. All cultivars tested were susceptible to PMTV but those with russet-skinned tubers were more tolerant to powdery scab than cultivars with yellow- or redskinned tubers, suggesting that root gall assessment is necessary for determining host tolerance or resistance to the PMTV vector. Under optimum conditions for powdery scab development, PMTV transmission was high, even in noninoculated potting mixes, indicating that peat-based potting mix is a medium for both $S$. subterranea and PMTV. These pathogens may be spreading in early generation seed potato due to their presence in potting mixes and because current chemical management methods for Spongospora diseases are either ineffective or result in an increase in soilborne inoculum when compared with potato crops without chemical treatments.
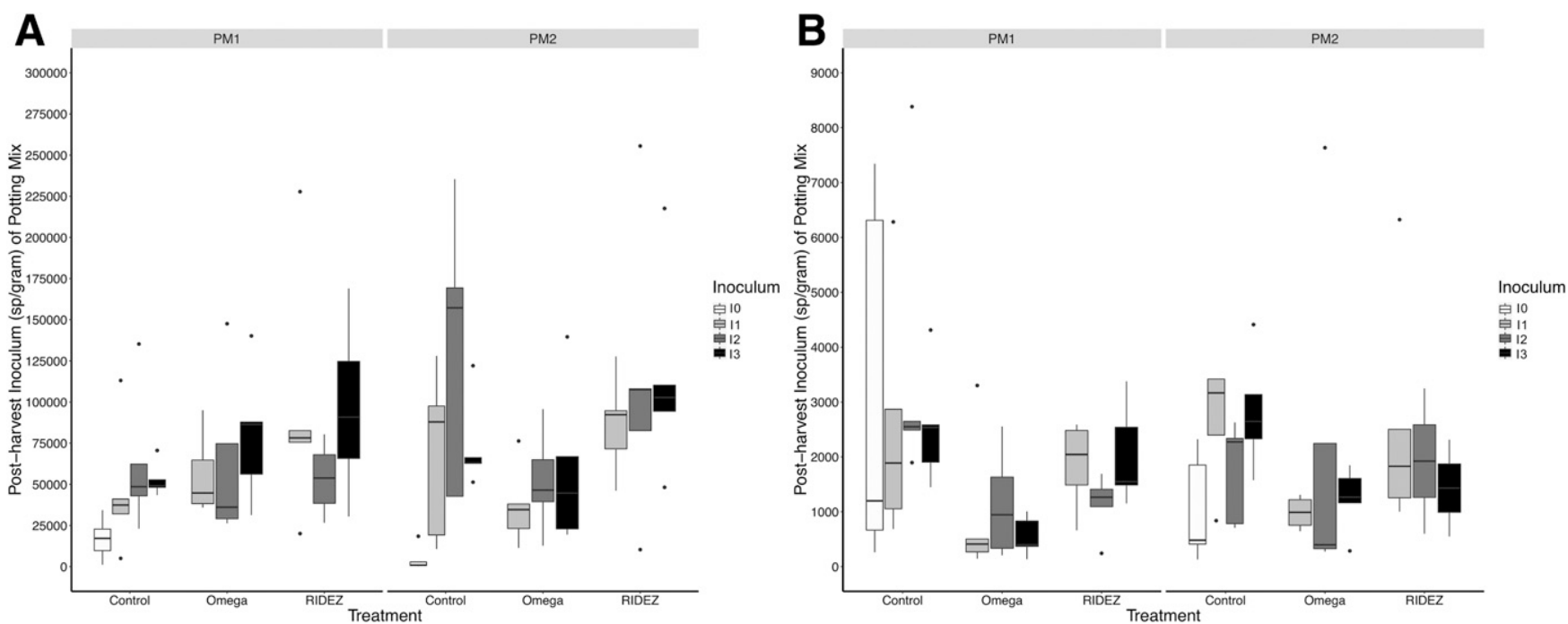

Fig. 5. Box plots of postharvest Spongospora subterranea inoculum (sporosori [sp] per gram of potting mix) among different treatments in the A, Satina trial and B, Diplomat trial in the greenhouse experiments. $10, I 1, I 2$, and $I 3$ represent $0,1,5$, and $10 \mathrm{sp} / \mathrm{g}$ of potting mix, respectively. 


\section{Acknowledgments}

We thank the Colorado Potato Growers and the CSU SLV Research Center for their collaborations.

\section{Literature Cited}

Awati, R., Bhattacharya, A., and Char, B. 2019. Rapid multiplication technique for production of high-quality seed potato (Solanum tuberosum L.) tubers. J. Appl. Biol. Biotechnol. 7:1-5.

Baldwin, S. J., Genet, R. A., Butler, R. C., and Jacobs, J. M. E. 2008. A greenhouse assay for powdery scab (Spongospora subterranea f. sp. subterranea) resistance in potato. Potato Res. 51:163-173.

Balendres, M. 2017. Biology and chemical ecology of Spongospora subterranea during resting spore germination: Towards a germinate/exterminate control approach for Spongospora diseases of potato. A dissertation submitted to University of Tasmania.

Bittara, F. G., Thompson, A. L., Gudmestad, N. C., and Secor, G. A. 2016. Field evaluation of potato genotypes for resistance to powdery scab on tubers and root gall formation caused by Spongospora subterranea. Am. J. Potato Res. 93:497-508.

Bittara-Molina, F. G. 2015. Studies on the development and management of powdery scab and root gall formation caused by Spongospora subterranea on potato (Solanum tuberosum L.). A dissertation submitted to the graduate faculty of the North Dakota State University of Agriculture and Applied Science.

Braithwaite, M., Falloon, R. E., Genet, R. A., Wallace, A. R., Fletcher, J. D., and Braam, W. F. 1994. Control of powdery scab of potatoes with chemical seed tuber treatments. N. Z. J. Crop Hortic. Sci. 22:121-128.

Brierley, J. L., Sullivan, L., Wale, S. J., Hilton, A. J., Kiezebrink, D. T., and Lees, A. K. 2013. Relationship between Spongospora subterranea f. sp. subterranea soil inoculum level, host resistance and powdery scab on potato tubers in the field. Plant Pathol. 62:413-420.

Carnegie, S. F., Saddler, G. S., and Peters, J. C. 2009. Cultivar susceptibility to Potato mop-top virus (PMTV) infection and symptom expression. Aspects Appl. Biol. 94:51-54.

Dandurand, L.-M., Zasada, I. A., Wang, X., Mimee, B., De Jong, W., Novy, R., Whitworth, J., and Kuhl, J. C. 2019. Current status of potato cyst nematodes in North America. Annu. Rev. Phytopathol. 57:117-133.

Davey, T., Carnegie, S. F., Saddler, G. S., and Mitchell, W. J. 2014. The importance of the infected seed tuber and soil inoculum in transmitting Potato mop-top virus to potato plants. Plant Pathol. 63:88-97.

Domfeh, O., Bittara, F. G., and Gudmestad, N. C. 2015. Sensitivity of potato cultivars to Potato mop-top virus induced tuber necrosis. Plant Dis. 99:788-796.

Falloon, R. E. 2008. Control of powdery scab of potato: Towards integrated disease management. Am. J. Potato Res. 85:253-260.

Falloon, R. E., Genet, R. A., Wallace, A. R., and Butler, R. C. 2003. Susceptibility of potato (Solanum tuberosum) cultivars to powdery scab (caused by Spongospora subterranea f. sp. subterranea), and relationships between tuber and root infection. Australas. Plant Pathol. 32:377-385.

Falloon, R. E., Merz, U., Butler, R. C., Curtin, D., Lister, R. A., and Thomas, S. M. 2016. Root infection of potato by Spongospora subterranea: Knowledge review and evidence for decreased plant productivity. Plant Pathol. 65:422-434

Falloon, R. E., Viljanen-Rollinson, S. L. H., Coles, G. D., and Poff, J. D. 1995. Disease severity keys for powdery and downy mildews of pea, and powdery scab of potato. N. Z. J. Crop Hortic. Sci. 23:31-37.

Falloon, R. E., Wallace, A. R., Braithwaite, M., Genet, R. A., Nott, H. M., Fletcher, J. D., and Braam, W. F. 1996. Assessment of seed tuber, infurrow, and foliar chemical treatments for control of powdery scab (Spongospora subterranea f. sp. subterranea) of potato. N. Z. J. Crop Hortic. Sci. 24:341-353.

Harrison, J. G., Searle, R. J., and Williams, N. A. 1997. Powdery scab disease of potato-A review. Plant Pathol. 46:1-25.

Houser, A. J., and Davidson, R. D. 2010. Development of a greenhouse assay to evaluate potato germplasm for susceptibility to powdery scab. Am. J. Potato Res. 87:285-298

Johnson, D. A., and Cummings, T. F. 2015. Effect of powdery scab root galls on yield of potato. Plant Dis. 99:1396-1403.

Jones, R. A. C., and Harrison, B. D. 1969. The behavior of Potato mop-top virus in soil, and evidence for its transmission by Spongospora subterranea (Wallr.) Lagerh. Ann. Appl. Biol. 63:1-17.

Kirk, H. G. 2008. Mop-top virus, relationship to its vector. Am. J. Potato Res. 85:261-265.

Larkin, R. P., and Griffin, T. S. 2007. Control of soilborne potato diseases using Brassica green manures. Crop Prot. 26:1067-1077.

Larkin, R. P., and Lynch, R. P. 2018. Use and effects of different Brassica and other rotation crops on soilborne diseases and yield of potato. Horticulturae 4:37.

Mallik, I., Fulladolsa, A. C., Yellareddygari, S. K. R., Bittara, F. G., Charkowski, A. O., and Gudmestad, N. C. 2019. Detection and quantification of
Spongospora subterranea sporosori in soil by quantitative real-time PCR. Plant Dis. 103:3189-3198.

Merz, U. 2000. Experiments on direct control and yield loss made in New Zealand Pages 51-52 in: Proc. First Eur. Powdery Scab Workshop.

Merz, U. 2008. Powdery scab of potato-Occurrence, life cycle and epidemiology. Am. J. Potato Res. 85:241-246.

Merz, U., and Falloon, R. E. 2009. Review: Powdery scab of potato-Increased knowledge of pathogen biology and disease epidemiology for effective disease management. Potato Res. 52:17-37.

Merz, U., Lees, A. K., Sullivan, L., Schwärzel, R., Hebeisen, T., Kirk, H. G. Bouchek-Mechiche, K., and Hofferbert, H. R. 2012. Powdery scab resistance in Solanum tuberosum: An assessment of cultivar $\times$ environment effect. Plant Pathol. 61:29-36.

Montero-Astúa, M., Vasquéz, V., Turechek, W. W., Merz, U., and Rivera, C. 2008. Incidence, distribution, and association of Spongospora subterraned and Potato mop-top virus in Costa Rica. Plant Dis. 92:1171-1176.

Muzhinji, N., and van der Waals, J. E. 2019. Population biology and genetic variation of Spongospora subterranea $\mathrm{f}$. sp. subterranea, the causal pathogen of powdery scab and root galls on potatoes in South Africa. Phytopathology 109:1957-1965.

Nachmias, A., and Krikun, J. 1988. Etiology and control of powdery scab of potato in a semi-arid region of Israel. Phytoparasitica 16:33-38.

Nakayama, T., Horita, M., and Shimanuki, T. 2007. Spongospora subterranea soil contamination and its relationship to severity of powdery scab on potatoes. J. Gen. Plant Pathol. 73:229-234.

Qu, X., Kavanagh, J. A., Egan, D., and Christ, B. J. 2006. Detection and quantification of Spongospora subterranea $\mathrm{f}$. sp. subterranea by PCR in host tissue and naturally infested soils. Am. J. Potato Res. 83:21-30.

Santala, J., Samuilova, O., Hannukkala, A., Latvala, S., Kortemaa, H., Beuch, U., Kvarnheden, A., Persson, P., Topp, K., Ørstad, K., Spetz, C., Nielsen, S. L., Kirk, H. G., Budziszewska, M., Wieczorek, P., Obrępalska-Stęplowska, A., Pospieszny, H., Kryszczuk, A., Sztangret-Wiśniewska, J., Yin, Z., Chrzanowska, M., Zimnock-Guzowska, E., Jackeviciene, E., Taluntytė, L., Pūpola, N., Mihailova, J., Lielmane, I., Järvekülg, L., Kotkas, K., Rogozina, E., Sozonov, A., Tikhonovich, I., Horn, P., Broer, I., Kuusiene, S., Staniulis, J., Uth, J. G., Adam, G., and Valkonen, J. P. T. 2010. Detection, distribution and control of Potato mop-top virus, a soil-borne virus, in northern Europe. Ann. Appl. Biol. 157:163-178.

Shah, F. A., Falloon, R. E., Butler, R. C., Lister, R. A., Thomas, S. M., and Curtin, D. 2014. Agronomic factors affect powdery scab of potato and amounts of Spongospora subterranea DNA in soil. Australas. Plant Pathol. 43:679-689.

Simango, K., and van der Waals, J. E. 2017. Effects of different soil treatments on the development of Spongospora subterranea $\mathrm{f}$. sp. subterranea in potato roots and tubers in the greenhouse. Potato Res. 60:47-60.

Tenorio, J., Franco, Y., Chuquillanqui, C., Owens, R. A., and Salazar, L. F. 2006 Reaction of potato varieties to Potato mop-top virus infection in the Andes. Am. J. Potato Res. 83:423-431.

Thangavel, T., Tegg, R. S., and Wilson, C. R. 2015. Monitoring Spongospora subterranea development in potato roots reveals distinct infection patterns and enables efficient assessment of disease control methods. PLoS One 10: e0137647.

Torres, H., Pacheco, M. A., and French, E. R. 1995. Resistance of potato to powdery scab (Spongospora subterranea) under Andean field conditions. Am. Potato J. 72:355-363.

Tsror, L., Erlich, O., Hazanovsky, M., and Zig, U. I. 2009. Powdery scab occurrence and control in Israel. Page 44 in: Abstr. 7th Int. Symp. Chem. Non-Chem. Soil Substrate Disinfestation. Katholieke Universiteit Leuven, Belgium

Tsror (Lahkim), L., Erlich, O., Hazanovsky, M., and Lebiush, S. 2019. Control of potato powdery scab (Spongospora subterranea) in Israel with chloropicrin, metam sodium or fluazinam. Crop Prot. 124:104836.

Tsror (Lahkim), L., Lebiush, S., Hazanovsky, M., and Erlich, O. 2020. Control of potato powdery scab caused by Spongospora subterranea by foliage cover and soil application of chemicals under field conditions with naturally infested soil. Plant Pathol. 69:1070-1082.

van de Graaf, P., Lees, A. K., Cullen, D. W., and Duncan, J. M. 2003. Detection and quantification of Spongospora subterranea in soil, water and plant tissue samples using real-time PCR. Eur. J. Plant Pathol. 109:589-597.

van de Graaf, P., Lees, A. K., Wale, S. J., and Duncan, J. M. 2005. Effect of soil inoculum level and environmental factors on potato powdery scab caused by Spongospora subterranea. Plant Pathol. 54:22-28.

van de Graaf, P., Wale, S. J., and Lees, A. K. 2007. Factors affecting the incidence and severity of Spongospora subterranea infection and galling in potato roots. Plant Pathol. 56:1005-1013.

Wale, S. J. 2000. Summary of the session on national potato production and the powdery scab situation. In: Proc. First Eur. Powdery Scab Workshop.

Wright, J., Lees, A. K., and van der Waals, J. E. 2012. Detection and eradication of Spongospora subterranea in mini-tuber production tunnels. S. Afr. J. Sci. 108: $85-88$ 